\title{
Environmentally friendly properties of vegetable oil methyl esters
}

Paul GATEAU ${ }^{1}$

François VAN DIEVOET ${ }^{2}$

Vincent BOUILLON ${ }^{2}$

Georges VERMEERSCH ${ }^{3}$

Sylvain CLAUDE ${ }^{4}$

Frédéric STAAT ${ }^{5}$

${ }^{1}$ Loire 2i.S, 21, rue de la Poterie, 44640 Saint-Jean de Boiseau, France <gateau.pau@wanadoo.fr>

${ }^{2}$ BFB Oil Research, Parc Scientifique Crealys, rue Phocas Lejeune 10, B-5032 Gembloux, Belgique

$<$ bfb@proximedia.be>

${ }^{3}$ Onidol, 12, avenue George V,

75008 Paris, France

$<$ g.vermeersch@prolea.com>

${ }^{4}$ Onidol, 12, avenue George V,

75008 Paris, France

$<$ s.claude@prolea.com>

5 Iterg, Rue Monge, Parc Industriel,

33600 Pessac, France

$<$ f.staat@iterg.com>

\begin{abstract}
Measurements were carried out on Vegetable Oil Methyl Esters (VOME or FAME) answering the most recent specifications. The products tested are RME (Rapeseed oil Methyl Ester), ERME (Erucic Rapeseed oil Methyl Esters), SME (Sunflower oil Methyl Esters), and HOSME (High Oleic Sunflower oil Methyl Esters). They contain more than $99.5 \%$ of fatty acid mono esters. The compositions are given. VOME are not volatile and they are not easily flammable. They are not soluble in water and they are biodegradable. According to the methods implemented for the determination of the German classification of substances hazardous to waters WGK, they are not toxic on mammals and unlike diesel fuel they are not toxic on fish, daphnia, algae and bacteria. The RME is not either toxic for shrimps. According to tests on rabbits, RME and SME are not irritating for the skin and the eyes. VOME display particularly attractive environmental properties.
\end{abstract}

Key words: vegetable oil methyl esters, fatty acid methyl esters, environmental properties, biodegradability, toxicity, ecotoxicity

In 2005, France will produce approximately 450,000 $\mathrm{T}$ of vegetable oil methyl esters (VOME/FAME) for diesel fuel use.

The data published on the biodegradability and ecotoxicity of VOMEs are incomplete and often obsolete. Measurements were sometimes carried out on products whose composition is far from the specifications required. Taking into account new emerging markets for VOMEs (lubricants and solvents) besides that of diesel fuels, it was necessary to bring these data up to date. That is why Onidol (National Inter Professional Oilseed Organisation) asked an independent laboratory (BFB Oil Research) to analyse four VOMEs and compare them to a reference diesel fuel CEC RF-73-A-93:

- Rapeseed oil Methyl Esters (RME),

- Erucic Rapeseed oil Methyl Esters (ERME),

- Sunflower oil Methyl Esters (SME)

- High Oleic Sunflower oil Methyl Esters (HOSME).

Some other test results on RME coming from the Marine Biology Laboratory of Concarneau are also provided here.

\section{Physical-chemical characteristics of the products tested}

\section{Composition of VOMEs}

VOMEs are manufactured by oil transesterification with methanol, so the fatty acid distribution is the same in esters and oils (tables 1 and 2).

Samples of RME, SME and HOSME result from industrial productions with distillation and fulfil the standards imposed on the European biofuels market. ERMEs were manufactured by ITERG (French Institute of Fatty Substances) in a small pilot unit. This explains its water content (300 ppm).

Physical-chemical characteristics of the reference fuel CEC RF-73-A-93 (tables 3 and 4)

The reference fuel is used to test the future diesel engines. Its characteristics comply with the specifications of table 3.

The aromatics content of the fuel was measured by HPLC according to the IP391 method.

\section{Environmental properties with respect to air}

\section{Vapour emissions of VOMEs}

VOMEs are non volatile products: the initial distillation point at atmospheric pressure is above $200^{\circ} \mathrm{C}$.

During the manufacturing process, methanol is eliminated by flash evaporation or distillation, avoiding alcoholic vapours formation during use.

This study was an opportunity to revisit some data. At ambient temperature, the saturated vapour pressure of fatty acid methyl esters is very weak and difficult to measure directly. The measurement 
Table 1. Composition in fatty acids (\%) of the 4 VOMEs.

\begin{tabular}{|lcccc|}
\hline & RME & ERME & SME & HOSME \\
\hline C14:0 & - & - & 0.1 & 0.1 \\
C16:0 & 4.5 & 3.0 & 5.8 & 4.1 \\
C16:1 & 0.2 & 0.2 & 0.2 & 0.2 \\
C17:1 & - & - & - & - \\
C18:0 & 1.5 & 1.0 & 4.5 & 4.0 \\
C18:1 & 57.8 & 15.1 & 21.0 & 77.3 \\
C18:2 & 22.7 & 13.5 & 67.4 & 12.5 \\
C18:3 & 9.6 & 9.0 & 0.1 & 0.2 \\
C20:0 & 0.6 & 0.7 & 0.2 & 0.5 \\
C20:1 & 1.5 & 8.1 & 0.4 & 0.5 \\
C20:2 & - & 0.5 & - & - \\
C22:0 & 1.3 & 0.1 & - & - \\
C22:1 & & 46.0 & 0.3 & 0.6 \\
C22:2 & - & 0.6 & - & - \\
C24:0 & - & 0.2 & - & - \\
C24:1 & - & 1.0 & - & - \\
\hline
\end{tabular}

Table 2. Physical-chemical characteristics of the 4 VOME.

\begin{tabular}{|lccccc|}
\hline \multirow{2}{*}{ Parameters } & \multirow{2}{*}{ Units } & \multicolumn{4}{c|}{ Results } \\
\cline { 3 - 6 } & & RME & ERME & SME & HOSME \\
\hline Water content & $\mathrm{ppm}(\mathrm{w} / \mathrm{w})$ & 177 & 328 & 160 & 180 \\
Acid Number & $\mathrm{mg} \mathrm{KOH} / \mathrm{g}$ & 0.23 & 0.21 & 0.16 & 0.10 \\
Ester content & $\%(\mathrm{w} / \mathrm{w})$ & 99.8 & 99.5 & 99.7 & 99.7 \\
Methanol content & $\mathrm{ppm}(\mathrm{w} / \mathrm{w})$ & 100 & $<10$ & 100 & 200 \\
Monoglycerides content & $\%(\mathrm{w} / \mathrm{w})$ & 0.14 & 0.038 & 0.15 & 0.15 \\
Diglycerides content & $\%(\mathrm{w} / \mathrm{w})$ & 0.01 & 0.003 & 0.01 & 0.01 \\
Triglycerides content & $\%(\mathrm{w} / \mathrm{w})$ & 0.003 & 0.002 & 0.003 & 0.003 \\
Free glycerol content & $\%(\mathrm{w} / \mathrm{w})$ & 0.03 & 0.055 & 0.01 & 0.02 \\
\hline
\end{tabular}

Table 3. Reference fuel specifications.

\begin{tabular}{|lc|}
\hline Density $15{ }^{\circ} \mathrm{C}$ & $835-845 \mathrm{~kg} / \mathrm{m}^{3}$ \\
Viscosity $40{ }^{\circ} \mathrm{C}$ & 2.5 to $3.5 \mathrm{~mm}^{2} / \mathrm{s}$ \\
$\mathrm{CFPP}$ & $<-5{ }^{\circ} \mathrm{C}$ \\
Distillation & \\
$50 \%$ & $>245{ }^{\circ} \mathrm{C}$ \\
$90 \%$ & $320-340{ }^{\circ} \mathrm{C}$ \\
final point & $<370{ }^{\circ} \mathrm{C}$ \\
Cetane number & $49-53$ \\
\hline
\end{tabular}

Table 4. Aromatic content of reference fuel.

\begin{tabular}{|lc|}
\hline Mono-aromatics & $25.8 \%$ weight \\
Di-aromatics & $5.8 \%$ weight \\
Tri-aromatics & $0.3 \%$ weight \\
Total aromatics & $\mathbf{3 1 . 9} \%$ weight \\
\hline
\end{tabular}

Table 5. Flammability of VOMEs.

\begin{tabular}{|llccccc|}
\hline & & EMC & EMT & EMTO & $\begin{array}{c}\text { Diesel Toluene } \\
\text { fuel }\end{array}$ & \\
\hline Flash Point $\left({ }^{\circ} \mathrm{C}\right)$ & ASTM D92 & 183 & 183 & 176 & $>55$ & 4 \\
Fire Point $\left({ }^{\circ} \mathrm{C}\right)$ & ASTM D92 & 190 & 195 & 204 & & \\
\hline
\end{tabular}

of the vapour pressure of RME is published here for the first time. It was obtained with an original gas saturation method with GC-FID detection [1]:

$P_{\text {RME }}\left(20 \pm 0.1^{\circ} \mathrm{C}\right)=(1.09 \pm 0.11) 10^{-3} \mathrm{~Pa}$

Therefore, measured volatility of RME is 10,000 times weaker than the VOC directive threshold $\left(\mathrm{P} \geq 10^{-2} \mathrm{kPa}\right.$ at $\left.20^{\circ} \mathrm{C}\right)$.

That value confirms the very low volatility of VOME and is in accordance with literature. At $25^{\circ} \mathrm{C}$, the reference [2] indicates $0.005 \mathrm{~Pa}$ for methyl palmitate (C16:0) and 0.001 Pa for all the C18 (stearate, oleate, linoleate and linolenate) methyl esters. The corresponding molar fractions of gaseous esters ( 0.01 to $0.05 \mathrm{ppm}$ ) in free atmosphere are 1,000 to 10,000 times weaker than mean limit values specified for the majority of industrial solvents. It can be concluded that the handling of VOME at moderate temperatures does not give rise to VOC (Volatile Organic Compounds) emissions.

\section{Flammable atmospheres}

The flash point is the temperature at which a liquid should be heated so that it can ignite under the passage of a pilot flame. The flame dies out when the pilot flame is withdrawn, except if the temperature has reached the fire point (table 5).

VOMEs are combustible but, by their low volatility, it is necessary to heat them strongly to make them flammable. So they show better safety characteristics than the majority of industrial solvents.

\section{Properties with respect to accidental spills}

\section{Solubility in water}

The C18 hydrocarbons solubility is lower than one ppm [3], but as the tested VOMEs are industrial products it was necessary to carry out a measurement. Two independent laboratories, BFB Oil Research and IFP (French Institute of Petroleum) were asked by Onidol to implement that delicate measurement with RME.

\section{Result from BFB Oil Research [4]}

Determination of RME solubility in water is carried out using guidelines from OECD 105, ASTM D 6081 and ISO 9377. A bidistilled rapeseed oil methyl ester is put down in excess on the surface of neutral pure water and mixed with a magnetic stirrer at a speed so that the resulting vortex is between $10-15 \%$ of total liquid height. After 30 minutes equilibrium time, water dissolved components are extracted and concentrated. The quantification is performed using an FID gas chromatograph under a calibration curve. Precautions have been taken to avoid biodegradation and hydrolysis.

The average of several determinations, with and without internal standard, have led to a hydrosolubility of $124 \mu \mathrm{g} / \mathrm{l}$ at $20^{\circ} \mathrm{C}$.

\section{Result from IFP [5]}

The aqueous solubility of a rape oil methyl ester solution has been assessed both using OECD method 105 and biphasic contact. The aqueous concentration of the different fatty acid methyl ester composing a bidistilled rape oil methyl ester has been analysed by solid phase micro extraction using a $100 \mu \mathrm{m}$ PDMS (polydimethylsiloxane) fibre from Supelco. The methyl esters of the following compounds (C16:0, C18:1, C18:2 and C18:3) were individually quantified after gas chromatography separation and flame ionisation detection. Calibration curves were obtained on standard solutions and have been established using the optimised analytical protocol.

For the sum of the methyl esters quantified, the results obtained at $20^{\circ} \mathrm{C}$ with the OECD test were $121 \mu \mathrm{g} / \mathrm{l}( \pm 17 \%)$ using a percolation water flow 
of $25,7 \mathrm{ml} / \mathrm{h}$ and $115 \mu \mathrm{g} / \mathrm{l}( \pm 4 \%$ ) with a water flow $9,4 \mathrm{ml} / \mathrm{h}$. These values are consistent with those obtained on biphasic contacts.

Both studies point out that the solubility of RME in water is approximately: $120 \mu \mathrm{g} / \mathrm{l}\left(20^{\circ} \mathrm{C}\right)$.

That value is far from the $1 \mathrm{ppm}(e . g .1 \mathrm{mg} / \mathrm{l})$ considered as threshold (low solubility) for the ecological impact assessment on water resources.

\section{Selected toxicity tests}

The tests of the German standard "Blue Angel" were retained for the 4 VOMEs (table 6) and a toxicity test on shrimps was also applied to RME.

\section{Oral toxicity on mammals according to the OECD 401 method}

This analysis was carried out on rats for BFB by "Hygiene Institute of Gelsenkirchen". Rats are fed with calculated amounts of the substance tested. The $L_{50}$ is the concentration which causes the death of $50 \%$ of the animals. It is expressed by the ratio between the weight of substance and the weight of animal $(\mathrm{mg} / \mathrm{kg})$.

\section{Sample preparation for aquatic toxicity testing and methodology WAF} (Water Accommodated Fraction)

A certain quantity of VOME is added to a nutritional solution. The amount is determined by the desired nominal exposure load [6]. For all the substances, loads of $10,1,0.1,0.01$ and $0.001 \%$ were tested.

Each mixture is stirred for $24 \mathrm{hrs}$ and allowed to settle for $4 \mathrm{hrs}$. The solution collected after decantation is noted WAF and is used for fish and daphnia toxicity tests.

Components dissolved in the water phase can be stable droplets or emulsion whose presence causes problems for optical density reading. This is the case for toxicity tests on algae and bacteria. For these tests, WAF is filtered through $2.3 \mu \mathrm{m}$ then $0.45 \mu \mathrm{m}$ filters to give a solution called WSF (Water Soluble Fraction).

For each method, the concentration resulting in a toxic effect is obtained by interpolation of the results obtained with the loads mentioned above. A methodology is specified for that, with reference to a pilot test.

Fish toxicity tests according to the OECD 203 method (ISO 9439)

The method consists in determining the concentration (WAF-Water Accommodated Fraction) which kills $50 \%$ of Brachydanio rerio (Teleostei, Cyprinidae) (Hamilton-Buchanan) also known as Zebrafish in 48 hrs. This lethal concentration is indicated by $\mathrm{LC}_{50-48 \mathrm{~h}}(\mathrm{WAF} \mathrm{mg} / \mathrm{ml})$.

Table 6. Tests of the standard "Blue Angel".

\begin{tabular}{|lc|}
\hline Test & Standards \\
\hline Oral toxicity on mammals & OECD 401 \\
Toxicity on fish & OECD 203 \\
Toxicity on daphnia & OCDE 202 \\
Toxicity on algae & OECD 201 \\
Toxicity on bacteria & ISO 10712 \\
Biodegradability & OECD 301B \\
\hline
\end{tabular}

10 fish were used for each concentration.

Daphnia toxicity test according to the OECD 202 method (ISO 6341)

The principle consists in determining the concentration present at the beginning of the test which, in $48 \mathrm{hrs}$, immobilizes $50 \%$ of Daphnia Magna put in experimentation. This effective concentration is indicated by $\mathrm{EC}_{50-48 \mathrm{~h}}(\mathrm{WAF} \mathrm{mg} / \mathrm{ml})$.

20 daphnia were used for each concentration, divided into 4 batches of 5 .

Algae toxicity test according to the OECD 201 method (ISO 8692)

The method consists in determining inhibition of the growth of Selenastrum capricornutum. 72 hours incubation is carried out for solutions of different concentrations and an identical culture without toxic substance. The inhibition of growth is followed by optical density. The $\mathrm{EC}_{50-72 \mathrm{~h}}$ (WAF $\mathrm{mg} / \mathrm{ml}$ ) result is the extrapolated concentration giving $50 \%$ of growth inhibition.

\section{Bacteria toxicity test according to ISO 10712 method}

The method consists in determining inhibition of growth of Pseudomonas putida. 16 hrs incubation is carried out with solutions of different concentrations and an identical culture without toxic substance. The inhibition of growth is followed by optical density. The $\mathrm{EC}_{0-16 \mathrm{~h}}(\mathrm{WAF} \mathrm{mg} / \mathrm{ml}$ ) result is the extrapolated concentration giving $0 \%$ of inhibition.

\section{Ultimate biodegradability test according to OECD $301 \mathrm{~B}$ method (ISO 9439)}

The modified Sturm test was applied. In a chemical solution without organic carbon, the substance to be tested is mixed with inoculums coming from activated sludge sampled from a domestic sewage treatment plant. Wavre city water treatment plant was selected because it is free from industrial effluents. $\mathrm{CO}_{2}$ released during 28 days is captured by a $\mathrm{Ba}(\mathrm{OH})_{2}$ solution in excess and $\mathrm{CO}_{2}$ amount is determined by back titration After comparison with a reference, the quantity of produced $\mathrm{CO}_{2}$ is translated into the percentage of total organic carbon of the substance.

The given results are the average of 2 tests at 2 different concentrations of about $20 \mathrm{mg}$ of carbon per litre.

\section{Results and comments}

The results of the six tests referred to above are reported in table 7. The 4 VOMEs, like the diesel fuel, are not orally toxic on mammals. For the other toxicity tests (bacteria, fish, daphnia, algae), it should be noted that diesel fuel always gives very bad results.

Concerning toxicity on daphnia, the significant differences between VOMEs and diesel fuel are confirmed in reference [7]. This study also reports rainbow trout behaviour. Those die after $72 \mathrm{hrs}$ with 1,200 ppm diesel fuel, while after 96 hours with 7,500 ppm of RMEs, all trouts are still alive.

Concerning biodegradability, the results obtained confirm the results indicated in the literature, namely a very good biodegradability of

Table 7. Results of the tests.

\begin{tabular}{|c|c|c|c|c|c|c|}
\hline Tests & Units & RME & ERME & SME & HOSME & Diesel Fuel \\
\hline Oral toxicity on mammals & $\mathrm{LD}_{50}(\mathrm{WAF} \mathrm{mg} / \mathrm{kg})$ & $>5,000$ & $>5,000$ & $>5,000$ & $>5,000$ & $>5,000$ \\
\hline Toxicity on fish & $\mathrm{LC}_{50-48 \mathrm{~h}}(\mathrm{WAF} \mathrm{mg} / \mathrm{l})$ & $>100,000$ & $>100,000$ & $>100,000$ & $>100,000$ & $<150$ \\
\hline Toxicity on daphnia & $\mathrm{EC}_{50-48 \mathrm{~h}}(\mathrm{WAF} \mathrm{mg} / \mathrm{l})$ & $>1,000$ & $>1,000$ & $>1,000$ & $>1000$ & $<100$ \\
\hline Toxicity on algae & $\mathrm{EC}_{50-72 \mathrm{~h}}(\mathrm{WAF} \mathrm{mg} / \mathrm{l})$ & $>10,000$ & $>10,000$ & $>10,000$ & $>100,000$ & $<100$ \\
\hline Toxicity on bacteria & $\mathrm{EC}_{0-16 \mathrm{~h}}(\mathrm{WAF} \mathrm{mg} / \mathrm{l})$ & $>1,000$ & $>1,000$ & $>1,000$ & $>1,000$ & $<10$ \\
\hline Ultimate biodegradability & $\%$ & 87 & 91 & 90 & 95 & 39 \\
\hline
\end{tabular}


VOMEs (> $87 \%$ ) whereas diesel fuel must be considered according to OECD 301 guidelines as not biodegradable (38.7\%).

In reference [8] according to the same method, rape and soy methyl esters lead to $88 \%$ biodegradation whereas a 2D diesel fuel (US fuel) leads to a value of $18 \%$.

\section{Determination of the WGK according to the method in effect before 2000}

$\mathrm{BZ}$ (beziehungsweise in German) means literally "respectively". BZ $Z_{S}, B Z_{B}$ and $B Z_{F}$, are calculated based on toxicity tests on mammals, bacteria and fish according to the formula: $B Z=6-\log _{10}$ (concentration in ppm). From their average value $\left(B Z_{S}+B Z_{B}+B Z_{F}\right) / 3$, one point is withdrawn if the product is more than $80 \%$ biodegradable and one point is added if there is bio-accumulation. The total gives WCZ. According to the value obtained, a hazardous to waters classification WGK (WGK = Wasser Gefährdungs-Klassen) is determined. Before 2000, the classification was the following:

\begin{tabular}{|lc|}
\hline WGZ & WGK \\
\hline $0-1.9$ & 0 non-hazardous to waters \\
$2-3.9$ & 1 slight hazard to waters \\
$4-5.9$ & 2 hazard to waters \\
$\geq 6.0$ & 3 severe hazard to waters \\
\hline
\end{tabular}

Diesel fuels and VOMEs are bio-accumulable. Table 8 gives the WGZ and WGK values calculated based on the preceding results.

In this classification, the four esters obtain a zero value for WGK: they are in the class of "non-hazardous to waters" product class. The reference diesel fuel with a WGK of 2 is in the "hazard to waters" product class.

\section{Determination of the WGK according to the new method since 2000}

Since 2000 , WGK $=0$ does not exist any more and has been replaced by meet "substances non-hazardous to waters". In order to qualify for it, the substance must fulfil all the following criteria:

- Total points must be 0 .

- Solubility in water $<10 \mathrm{mg} / \mathrm{l}$.

- No toxicity at saturation level (tested with at least two organisms fishes, daphnia or algae).

- Easily biodegradable.

The new classification is as follows:

\begin{tabular}{|lc|}
\hline Total number of points & WGK \\
\hline 0 (and all criteria above) & substance non-hazardous to waters \\
$0-4$ & 1 low hazard to waters \\
$5-8$ & 2 hazard to waters \\
$\geq 9$ & 3 severe hazard to waters \\
\hline
\end{tabular}

The attribution of the points is carried out on the basis of following tests (tables 9 and 10):

- Toxicity on mammals,

- The most significant data of toxicity on daphnia, fish or algae,

- Biodegradability and

- Potential for bioaccumulation.

According to test results in table 7 and taken into account the potential for bioaccumulation, the number of points attributed to RME is 0 which is the first criteria to fulfil a 'non-hazardous to waters' substance.

The complementary analyses have been performed on bidistilled RME showing a hydrosolubility at $20^{\circ} \mathrm{C}$ of $120 \mu \mathrm{g} / \mathrm{kg}$ (lower than $10 \mathrm{mg} / \mathrm{l}$ ).
Table 8. WGZ and WGK calculations (method before 2000).

\begin{tabular}{|c|c|c|c|c|c|}
\hline Tests & RME & ERME & SME & HOSME & $\begin{array}{l}\text { Diesel } \\
\text { Fuel }\end{array}$ \\
\hline $\begin{array}{l}\text { Oral toxicity on mammals } \\
\mathrm{BZ}_{\mathrm{S}}\end{array}$ & 1 & 1 & 1 & 1 & 1 \\
\hline Toxicity on bacteria $\mathrm{BZ}_{\mathrm{B}}$ & 2.28 & 2.90 & 2.99 & 2.20 & 5 \\
\hline Toxicity on fish $\mathrm{BZ}_{\mathrm{F}}$ & 1 & 1 & 1 & 1 & 3.9 \\
\hline$\left(B Z_{S}+B Z_{B}+B Z_{F}\right) / 3$ & 1.43 & 1.63 & 1.66 & 1.4 & 3.3 \\
\hline Biodegradability bonus & -1 & -1 & -1 & -1 & \\
\hline Bioaccumulation malus & 1 & 1 & 1 & 1 & 1 \\
\hline WGZ & 1.43 & 1.63 & 1.66 & 1.4 & 4.3 \\
\hline WGK & 0 & 0 & 0 & 0 & 2 \\
\hline
\end{tabular}

Table 9. Selected tests (toxicity on mammals).

\begin{tabular}{|lccc|}
\hline Exposure & $\begin{array}{c}\mathbf{L D}_{50} \text { in } \mathbf{~ m g} / \mathbf{k g} \\
\text { body weight }\end{array}$ & $\begin{array}{c}\text { R-phrase } \\
\text { Oral }\end{array}$ & $\begin{array}{c}\text { Evaluation } \\
\text { points }\end{array}$ \\
Dermal & $\mathrm{LD}_{50} \geq 2000$ & - & 0 point \\
Oral & $\mathrm{LD}_{50} \geq 2000$ & - & 0 point \\
Dermal & $200<\mathrm{LD}_{50} \leq 2000$ & $\mathrm{R} 22$ & 1 point \\
Oral & $400<\mathrm{LD}_{50} \leq 2000$ & $\mathrm{R} 21$ & 1 point \\
Dermal & $25<\mathrm{LD}_{50} \leq 200$ & $\mathrm{R} 25$ & 3 points \\
Oral & $50<\mathrm{LD}_{50} \leq 400$ & $\mathrm{R} 24$ & 3 points \\
Dermal & $\mathrm{LD}_{50} \leq 25$ & $\mathrm{R} 28$ & 5 points \\
\hline
\end{tabular}

Acute toxicity tests conducted using WAF or Soja lecithin to be sure to reach the saturation level concentration showed no toxicity at saturation level on at least two organisms (fishes and daphnia).

RME is readily biodegradable.

In conclusion, taken into account the data above, the RME must be considered as non-hazardous to waters.

Diesel fuel stays in a WGK equal to 2.

\section{Tests on batches of shrimps}

To be approved for the cleaning of coastlines spoiled by hydrocarbon spills, the wash products must comply with a procedure recommended by the CEDRE (French Research and Experimentation Centre on accidental pollution of water). This procedure was applied to RME. Analyses were carried out by the Marine Biology Laboratory of Concarneau [9].

The method consists in leaving shrimps for 6 hours in tanks containing the products being tested at various concentrations. Afterwards, the shrimps are put in sea water and mortality is examined at the end of 24 hours.

To avoid the influence of the physiological state of the animals, a preliminary test of sensitivity is carried out with lauryl-dimethyl-benzylammonium chloride marketed under the name of Noramium DA50 [supplier CECA (ATO FINA)] with concentrations ranging between 20 and $120 \mathrm{mg} / \mathrm{l}$. For all the tests, the shrimps come from the same batch. The results are given in table 11 .

The lethal amount of RME is 1,000 times higher than that of the reference product. It can be underlined that to be approved by the CEDRE, a ratio higher than 10 is enough.

\section{Contact with skin and eyes}

The tests were carried out according to the OECD 404 and 405 methods on male New Zealand Albino Rabbits. 
Table 10. WGK calculations (method after 2000).

\begin{tabular}{|c|c|c|c|c|c|}
\hline \multirow[t]{2}{*}{ Biodegradability } & \multirow[t]{2}{*}{ Potential for bioaccumulation } & \multicolumn{4}{|c|}{$\begin{array}{c}\text { Aquatic toxicity }\left(\mathrm{LC}_{50}, \mathrm{EC}_{50}, \mathrm{IC}_{50}\right) \mathrm{im} \mathrm{mg} / \mathrm{I} \\
\text { (most sensitive organism) }\end{array}$} \\
\hline & & $>100$ & $10-\leq 100$ & $1-\leq 10$ & $\leq 1$ \\
\hline \multirow{4}{*}{$\begin{array}{l}\text { Readily degradable } \text { (corresponding }^{\text {a }} \\
\text { to OECD 301) }\end{array}$} & Yes & 0 point & 0 point & 6 points & 8 points \\
\hline & & & & $\mathrm{R} 51 / 53$ & $\mathrm{R} 50 / 53$ \\
\hline & No & 0 point & 0 point & 0 point & 6 points \\
\hline & & & & & R50 \\
\hline \multirow{4}{*}{$\begin{array}{l}\text { Inherently (but possibly not readily) } \\
\text { degradable }^{\text {b }}\end{array}$} & Yes & 0 point & 0 point & 6 points & 8 points \\
\hline & & & & $\mathrm{R} 51 / 53$ & $\mathrm{R} 50 / 53$ \\
\hline & No & 0 point & 0 point & 6 points & 8 points \\
\hline & & & & $\mathrm{R} 51 / 53$ & R50/53 \\
\hline \multirow{4}{*}{$\begin{array}{l}\text { Not readily and/or not inherently } \\
\text { degradable }\end{array}$} & Yes & 3 points & 4 points & 6 points & 8 points \\
\hline & & R53 & $\mathrm{R} 52 / 53$ & $\mathrm{R} 51 / 53$ & $\mathrm{R} 50 / 53$ \\
\hline & No & 0 point & 4 points & 6 points & 8 points \\
\hline & & & $\mathrm{R} 52 / 53$ & $\mathrm{R} 51 / 53$ & $\mathrm{R} 50 / 53$ \\
\hline
\end{tabular}

a $10 \mathrm{~d}$ window is not taken into account in the evaluation of the test on ready biodegradability.

${ }^{\mathrm{b}}$ Substances are inherently biodegradable if they are mineralised in a test on inherent degradability to an extent of more than 60/70 \% (oxygen demand/DOC elimination) within 28 days. In the test according to OECD 302B, however, the $70 \%$ mark must be attained within 7 days.

Table 11. RME toxicity on shrimps.

\begin{tabular}{|lc|}
\hline Product & $\mathrm{LC}_{50}$ \\
Noramium DA 50 & $35.6 \mathrm{ppm}$ \\
RME & $37,598 \mathrm{ppm}$ \\
\hline
\end{tabular}

Table 12. Evaluation of dermal lesions according to OECD 404 method.

\begin{tabular}{|lll|}
\hline Note & Erythema & CEdema \\
\hline 0 & No erythema & No œdema \\
1 & Very slight erythema & Very slight œdema \\
2 & Well defined erythema & Slight œdema \\
3 & Moderate to severe erythema & Moderate œdema \\
4 & Severe erythema & Severe œdema \\
\hline
\end{tabular}

\section{Description of the acute dermal irritation assay according to the OECD 404 method}

$0.5 \mathrm{ml}$ of the test substance on a filter paper are put in contact with the skin of a rabbit by means of an hypoallergenic semi-adhesive plaster during $4 \mathrm{hrs}$. The patch is taken off and the animal is observed for signs of erythema and oedema 1, 24, 48 and 72 hours after patch removal. Dermal reaction of the skin is judged using the scale given thereafter (table 12).

\section{Description of the ocular irritation assay according to the OECD 405 method}

The method consists in injecting $0.1 \mathrm{ml}$ of substance in one of the eyes of a rabbit. The other eye is used as a reference. The eyes are examined at the end of 1,24, 48 and 72 hours. After an examination of the cornea, iris and the conjunctive, ocular reactions are quoted (table 13).

Table 13. Quotations of ocular reactions according to the OECD 405 method.

\begin{tabular}{|lllll|}
\hline Note & Cornea & Iris & \multicolumn{1}{c|}{ Conjunctives } & \\
\hline & & & Redness & Tumefaction \\
0 & No opacity & Normal & Normal blood vessels & No tumefaction \\
1 & Opacity zones & Deeper folds & Clear hyperhemy & Higher than normal \\
2 & Translucent & Marked destruction & Crimson coloration & Obvious tumefaction \\
3 & Pearly zones & & Red coloration & With half closed eyelids \\
4 & Opaque & & & $>$ Half closed eyelids \\
\hline
\end{tabular}

Table 14. Results of RME dermal effects according to the OECD 404 method.

\begin{tabular}{|lcccccccc|}
\hline Rabbits & \multicolumn{2}{c}{$\mathbf{1}$ hour } & \multicolumn{2}{c}{$\mathbf{2 4}$ hours } & \multicolumn{2}{c}{$\mathbf{4 8}$ hours } & \multicolumn{2}{c|}{$\mathbf{7 2}$ hours } \\
\cline { 2 - 9 } & Erythema & Cdema & Erythema & Cedema & Erythema & Cedema & Erythema & Cdema \\
\hline 1 & 1 & 0 & 0 & 0 & 0 & 0 & 0 & 0 \\
2 & 1 & 0 & 0 & 0 & 0 & 0 & 0 & 0 \\
3 & 1 & 0 & 0 & 0 & 0 & 0 & 0 & 0 \\
\hline
\end{tabular}


Table 15. Results of RME ocular effects according to the OECD 405 method.

\begin{tabular}{|c|c|c|c|c|c|c|c|c|c|c|c|c|c|c|c|c|}
\hline \multirow[t]{3}{*}{ Rabbits } & \multicolumn{4}{|c|}{1 hour } & \multicolumn{4}{|c|}{24 hours } & \multicolumn{4}{|c|}{48 hours } & \multicolumn{4}{|c|}{72 hours } \\
\hline & \multirow[t]{2}{*}{ Corn } & \multirow[t]{2}{*}{ Iris } & \multicolumn{2}{|c|}{ Conjunctives } & \multirow[t]{2}{*}{ Corn } & \multirow[t]{2}{*}{ Iris } & \multicolumn{2}{|c|}{ Conjunctives } & \multirow[t]{2}{*}{ Corn } & \multirow[t]{2}{*}{ Iris } & \multicolumn{2}{|c|}{ Conjunctives } & \multirow[t]{2}{*}{ Corn } & \multirow[t]{2}{*}{ Iris } & \multicolumn{2}{|c|}{ Conjunctives } \\
\hline & & & Red & Tum & & & Red & Tum & & & Red & Tum & & & Red. & Tum \\
\hline 1 & 0 & 0 & 2 & 0 & 0 & 0 & 0 & 0 & 0 & 0 & 0 & 0 & 0 & 0 & 0 & 0 \\
\hline 2 & 0 & 0 & 2 & 0 & 0 & 0 & 0 & 0 & 0 & 0 & 0 & 0 & 0 & 0 & 0 & 0 \\
\hline 3 & 0 & 0 & 2 & 0 & 0 & 0 & 0 & 0 & 0 & 0 & 0 & 0 & 0 & 0 & 0 & 0 \\
\hline
\end{tabular}

Table 16. Results of SME dermal effects according to the OECD 404 method.

\begin{tabular}{|c|c|c|c|c|c|c|c|c|}
\hline \multirow[t]{2}{*}{ Rabbits } & \multicolumn{2}{|c|}{1 hour } & \multicolumn{2}{|c|}{24 hours } & \multicolumn{2}{|c|}{48 hours } & \multicolumn{2}{|c|}{72 hours } \\
\hline & Erythema & CEdema & Erythema & Cdema & Erythema & Cdema & Erythema & Cdema \\
\hline 1 & 0 & 0 & 0 & 0 & 0 & 0 & 0 & 0 \\
\hline 2 & 0 & 0 & 0 & 0 & 0 & 0 & 0 & 0 \\
\hline 3 & 0 & 0 & 0 & 0 & $2^{\mathrm{a}}$ & 0 & $2^{\mathrm{a}}$ & 0 \\
\hline
\end{tabular}

${ }^{a}$ the observed reaction was local and not on all patch area.

Table 17. Results of SME ocular effects according to the OECD 405 method.

\begin{tabular}{|c|c|c|c|c|c|c|c|c|c|c|c|c|c|c|c|c|}
\hline \multirow[t]{3}{*}{ Rabbits } & \multicolumn{4}{|c|}{1 hour } & \multicolumn{4}{|c|}{24 hours } & \multicolumn{4}{|c|}{48 hours } & \multicolumn{4}{|c|}{72 hours } \\
\hline & \multirow[t]{2}{*}{ Corn } & \multirow[t]{2}{*}{ Iris } & \multicolumn{2}{|c|}{ Conjunctives } & \multirow[t]{2}{*}{ Corn } & \multirow[t]{2}{*}{ Iris } & \multicolumn{2}{|c|}{ Conjunctives } & \multirow[t]{2}{*}{ Corn } & \multirow[t]{2}{*}{ Iris } & \multicolumn{2}{|c|}{ Conjunctives } & \multirow[t]{2}{*}{ Corn } & \multirow[t]{2}{*}{ Iris } & \multicolumn{2}{|c|}{ Conjunctives } \\
\hline & & & Red & Tum & & & Red & Tum & & & Red & Tum & & & Red & Tum \\
\hline 1 & 1 & 0 & 2 & 2 & 0 & 0 & 0 & 0 & 0 & 0 & 0 & 0 & 0 & 0 & 0 & 0 \\
\hline 2 & 0 & 0 & 2 & 2 & 0 & 0 & 0 & 0 & 0 & 0 & 0 & 0 & 0 & 0 & 0 & 0 \\
\hline 3 & 0 & 0 & 2 & 2 & 0 & 0 & 0 & 0 & 0 & 0 & 0 & 0 & 0 & 0 & 0 & 0 \\
\hline
\end{tabular}

\section{Results of the tests}

Each test was carried out on 3 rabbits (table 14). The following tables present the various notes obtained for RME and SME.

By forming only one hardly perceptible erythema which disappears quickly, RME is not irritating for the skin (table 15).

RME injection causes redness at once but they disappea: SME is neither irritating nor corrosive for the eyes.

Within the limits of the assay, SME is not irritating for the skin (table 16). SME injection causes redness and tumefaction at once but they disappear: SME is neither irritating nor corrosive for the eyes (table 17).

\section{Conclusion}

The whole of the results obtained shows that VOME resulting from various oleaginous seeds have a better biodegradability and a lesser ecotoxicity than a Diesel reference fuel.

These results are very interesting for the biofuel market. They can also be emphasized for applications in other sectors (solvents and lubricants) where the environmental advantages of VOME will bring an undeniable advantage.

Another significant environmental advantage of these esters was not mentioned in this text. It is their favourable impact on greenhouse effect. Many publications deal with this point. We will underline only that of Etienne Poitrat [10] where the use of one tonne of EMC as diesel fuel is estimated to save $2.1 \mathrm{~T}$ of $\mathrm{CO}_{2}$.

These environmental benefits combined with their functionality mean that the derivatives of vegetable oils will play a significant role in the chemistry of the 21 st century.
REFERENCES

1. Professor Jacques JOSE, Université Claude Bernard - Lyon I, CNRS-UMR 5180, 43 Bd du 11 novembre, 69622 Villeurbanne Cedex, France.

2. KROP HB, VELZEN MJM, PARSONS JR, GOVERS HAJ. Determination of Environmentally Relevant Physical-Chemical Properties of Some Fatty Acid Esters. JAOCS 1997; 74(3): 309-15.

3. YAWS CL, YANG HC, HOPPER JR, HANSEN KC. Organic Chemicals: Water solubility data. Chemical Engineering July 1990: 115-8.

4. BOUILLON V, VAN DIEVOET F. Results to be published. BFB Oil Research, Parc Scientifique Crealys, rue Phocas Lejeune 10, B-5032 Gembloux, Belgique.

5. LE ROUX F, LE PENNEC D, HILLION G, ROPARS M, HAESELER F. Results to be published. IFP, 1et 4 avenue de Bois-Préau, 92852 Rueil-Malmaison Cedex, France.

6. ASTM D 6081-97. Standard Practice for Aquatic Toxicity Testing of Lubricants: Sample Preparation and Results Interpretation.

7. REECE D, PETERSON C. Acute toxicity of biodiesel to freshwater and marine organisms. Proc Biomass Conf Am 2 nd 1995: 931-40.

8. ZHANG X, PETERSON C, REECE D. Biodegradability of Biodiesel in Aquatic and Soil Environments. Conf. proceedings, Commercialization of Biodiesel. May 1996; 21-22: 97-107.

9. BEAUPOIL C, NEDELEC D. Contrôle de la toxicité, vis-à-vis de la crevette blanche Palaemonetes varians, du produit de lavage "diester". Station de biolologie marine, 29900 Concarneau, France.

10. POITRAT E. General Assembly of AMSOL. Paris, November 5, 2004. 